PHYSIOLOGY OF THE NERVOUS SYSTEM 


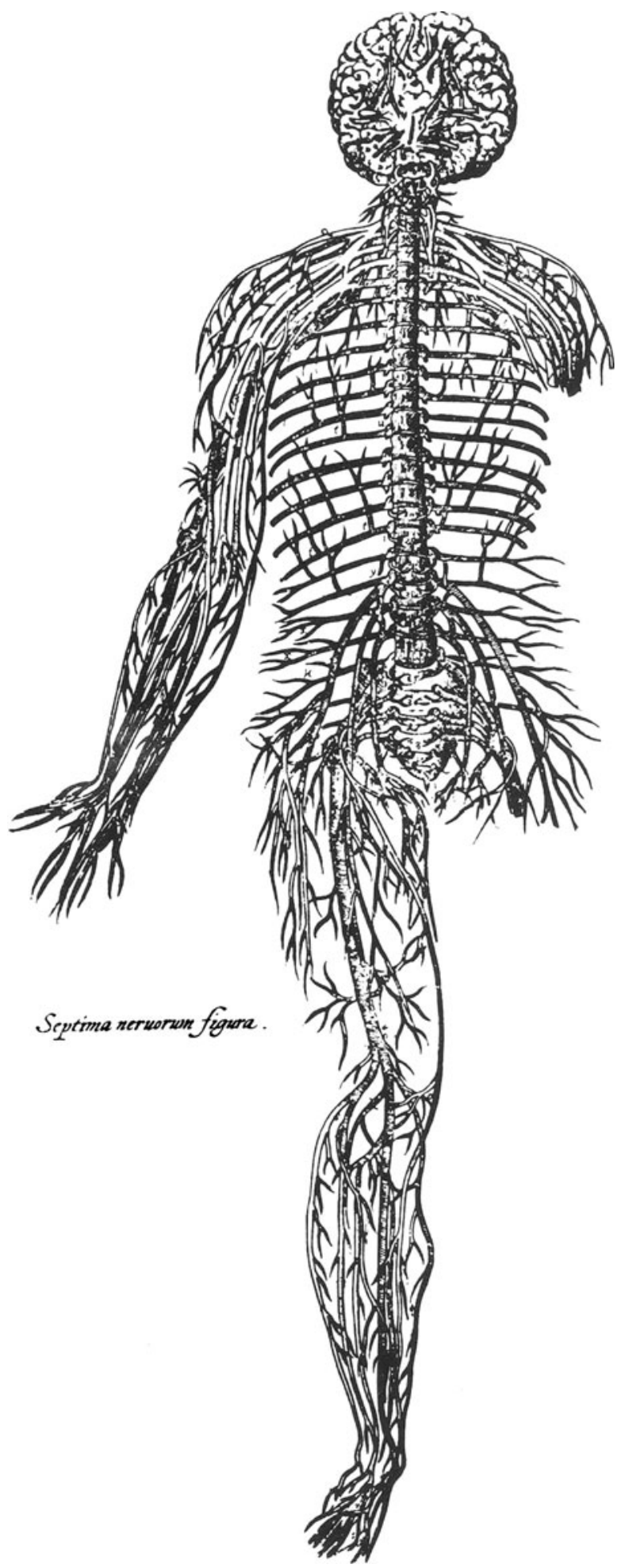




\section{Physiology of the Nervous System}

\section{DAVID OTTOSON}

Department of Physiology II,

Karolinska Institutet, Stockholm, Sweden 
(C) D. Ottoson 1983

All rights reserved. No part of this publication may be reproduced or transmitted, in any form or by any means, without permission.

First published 1983 by

THE MACMILLAN PRESS LTD

London and Basingstoke

Companies and representatives throughout the world

ISBN 978-0-333-30819-6 ISBN 978-1-349-16995-5 (eBook)

DOI 10.1007/978-1-349-16995-5

Typeset by

STYLESET LIMITED

Salisbury, Wiltshire

The paperback edition of the book is sold subject to the condition that it shall not, by way of trade or otherwise, be lent, resold, hired out, or otherwise circulated without the publisher's prior consent in any form of binding or cover other than that in which it is published and without a similar condition including this condition being imposed on the subsequent purchaser. 


\section{Contents}

Foreword $\quad$ xi

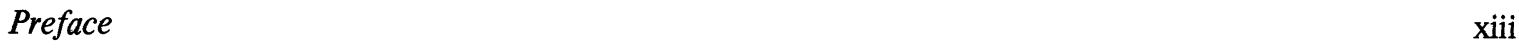

Acknowledgments $\quad$ xv

\begin{tabular}{ll}
\hline SECTION I: INTRODUCTION & 1 \\
\hline
\end{tabular}

1 HISTORICAL SURVEY $\quad 3$

$\begin{array}{lr}\text { BIBLIOGRAPHY FOR SECTION I } & 10\end{array}$

2 THE NEURON $\quad 13$

$\begin{array}{lll}2.1 & \text { Structure of the neuron } & 13\end{array}$

\begin{tabular}{ll}
2.2 & Nerve regeneration \\
\hline
\end{tabular}

2.3 Axoplasmic flow $\quad 44$

$\begin{array}{lll}2.4 & \text { The origin of the membrane potential } & 47\end{array}$

$\begin{array}{ll}2.5 & \text { The action potential } \\ 2.6 & 57\end{array}$

$\begin{array}{ll}2.6 & \text { Impulse conduction }\end{array}$

$\begin{array}{lll}2.7 & \text { Non-conducted neuronal activity } & 73\end{array}$

$\begin{array}{lll}2.8 & \text { Artificial membranes } & 75\end{array}$

$\begin{array}{lll}2.9 & \text { Electric organs } & 75\end{array}$

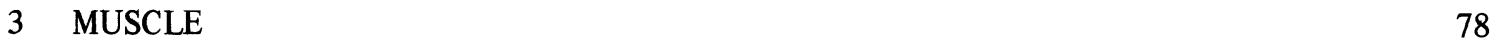

$\begin{array}{lll}3.1 & \text { Skeletal muscle } & 78\end{array}$

3.2 Muscle contraction $\quad 86$

$\begin{array}{llr}3.3 & \text { Smooth muscle } & 98\end{array}$

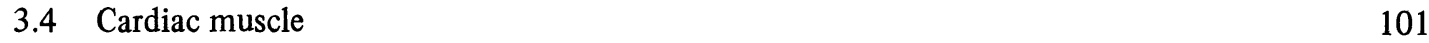

$\begin{array}{ll}3.5 & \text { Neuromuscular transmission } \\ \end{array}$

$\begin{array}{ll}\text { BIBLIOGRAPHY FOR SECTION II } & 117\end{array}$ 
4 STRUCTURAL AND FUNCTIONAL FEATURES OF SENSORY END ORGANS

$\begin{array}{lll}4.2 & \text { Transducer functions of receptor cells } & 133\end{array}$

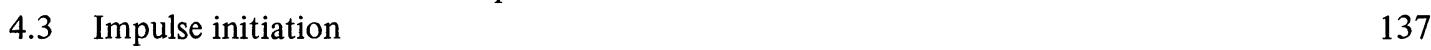

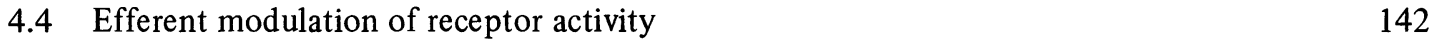

$\begin{array}{ll}4.5 & \text { Lateral inhibition } \\ & 142\end{array}$

$\begin{array}{ll}\text { BIBLIOGRAPHY FOR SECTION III } & 147\end{array}$

SECTION IV: THE SPINAL CORD

$5 \quad$ FUNCTIONAL ORGANISATION OF THE SPINAL CORD 153

5.1 General arrangement of white and grey matter 153

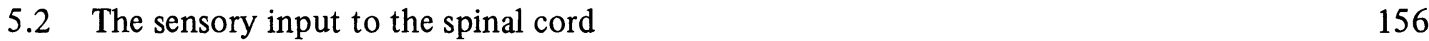

$\begin{array}{lll}5.3 & \text { Structural organisation of the dorsal horn } & 158\end{array}$

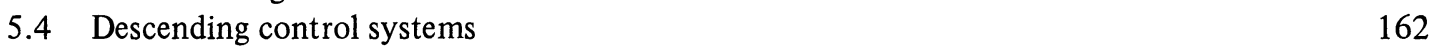

6 SPINAL REFLEXES

$\begin{array}{lll}\text { 6.1 The stretch reflex } & 164\end{array}$

$\begin{array}{lll}6.2 & \text { The flexor reflex } & 173\end{array}$

$\begin{array}{ll}6.3 \text { Postural reflexes } & 177\end{array}$

$\begin{array}{ll}\text { BIBLIOGRAPHY FOR SECTION IV } & 179\end{array}$

$7 \quad$ SYNAPTIC POTENTIALS $\quad 185$

$\begin{array}{lll}7.1 & \text { Excitatory and inhibitory synaptic potentials } & 185\end{array}$

$\begin{array}{lll}7.2 & \text { Impulse generation } & 188\end{array}$

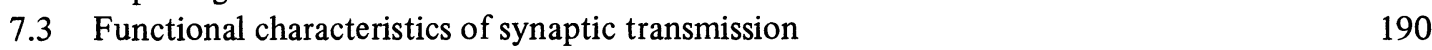

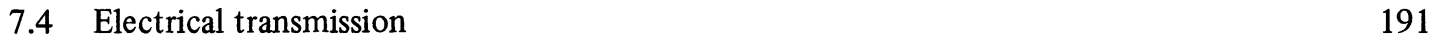

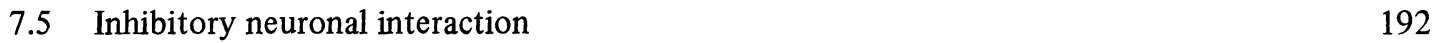

8 PUTATIVE TRANSMITTERS 196

$\begin{array}{ll}\text { BIBLIOGRAPHY FOR SECTION V } & 204\end{array}$ 
SECTION VI: THE CEREBRAL CORTEX: DEVELOPMENT, STRUCTURE

9 HISTORICAL SURVEY 209

$\begin{array}{llr}10 & \text { DEVELOPMENT OF THE BRAIN } & 214\end{array}$

11 THE CYTOARCHITECTURE AND CELLULAR ORGANISATION OF THE CEREBRAL CORTEX $\quad 219$

12 THE SOMATOSENSORY SYSTEM 226

13 THE RETICULAR SYSTEM 234

14 ELECTRICAL ACTIVITY OF THE BRAIN 237

$\begin{array}{ll}\text { BIBLIOGRAPHY FOR SECTION VI } & 244\end{array}$

\begin{tabular}{lr}
\hline SECTION VII: CENTRAL CONTROL OF LOCOMOTION & 247
\end{tabular}

15 CORTICAL CONTROL 249

$\begin{array}{ll}15.1 \text { Somatotopic organisation } & 249\end{array}$

15.2 The cortical command signal 255

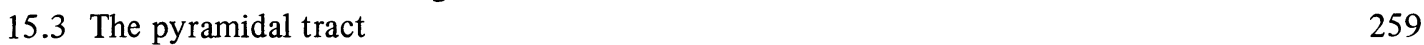

16 SUBCORTICAL CONTROL SYSTEMS 262

16.1 The extrapyramidal system $\quad 262$

16.2 Organisation of corticospinal motor control in the spinal cord 263

$\begin{array}{llr}17 & \text { THE CEREBELLUM } & 267\end{array}$

$\begin{array}{ll}\text { BIBLIOGRAPHY FOR SECTION VII } & 276\end{array}$

SECTION VIII: NEURAL CONTROL OF VISCERAL FUNCTIONS AND BEHAVIOUR 279

18 THE AUTONOMIC NERVOUS SYSTEM 281

19 NEUROPHYSIOLOGY OF BEHAVIOUR 286

19.1 The limbic system $\quad 286$

$\begin{array}{ll}19.2 \text { Hypothalamic control functions } & 288\end{array}$

$\begin{array}{ll}19.3 \text { Temperature regulation } & 290\end{array}$

$\begin{array}{ll}19.4 \text { Regulation of food intake } & 291\end{array}$

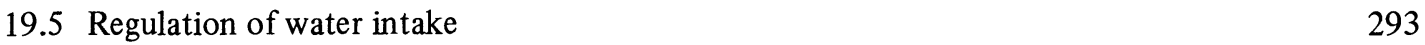


20 THE PHYSIOLOGICAL CLOCK 297

21 SLEEP AND WAKEFULNESS 301

$\begin{array}{lr}\text { BIBLIOGRAPHY FOR SECTION VIII } & 311\end{array}$

22 SPEECH FUNCTIONS

23 THE SPLIT BRAIN

BIBLIOGRAPHY FOR SECTION IX

24 THE NEURAL BASIS OF PERCEPTION

25 VISION

25.1 The optics of the eye

25.2 The anatomy of the eye

25.3 The fine structure of the retina

25.4 Spectral sensitivity of the eye

25.5 The photochemical basis of vision

25.6 Information processing in the retina

25.7 Cortical processing of visual information

25.8 Plasticity of the visual system

25.9 Colour vision

26 HEARING $\quad 395$

26.1 The functional anatomy of the inner ear $\quad 395$

26.2 Transmission of sound stimuli to the sensory cells 404

26.3 Electrical activity of the cochlea $\quad 409$

26.4 Central auditory pathways $\quad 412$

27 VESTIBULAR FUNCTIONS $\quad 415$

$\begin{array}{llr}28 & \text { TASTE } & 424\end{array}$

29 OLFACTION $\quad 429$

29.1 Functional anatomy of the olfactory system 429

29.2 The electrical activity of the olfactory system 440 
31.1 The functional anatomy of pain

31.2 Synaptic transmission of pain impulses in the spinal cord

31.3 Pain from different organ systems

31.4 Physiological mechanisms of pain modulation

31.5 Neurohumoural mechanisms for pain inhibition

485

31.6 Transcutaneous nerve stimulation

31.7 Acupuncture and pain

31.8 Hypnosis and pain

32 SENSORY DEPRIVATION 


\section{Foreword}

Physiology of the Nervous System was originally published in Swedish and immediately became very popular among medical students and university biology students. The reason then, as now, was that there was no other 'middle-sized' book that gave a succinct but still sufficiently scholarly treatment of the nervous system. David Ottoson is able to do just that in his descriptions spanning the biophysics of nerve impulse conduction and synaptic transmission through integration to higher brain functions. The presentation of the physiology is balanced by a description of essential morphological characteristics of the nervous system and a discussion of the neurochemistry of synapses. Thus it is possible to read and enjoy the book even if one has only limited previous knowledge about brain function. The short historical vignettes provide the reader with a useful perspective.

It is increasingly rare for a single author to be able to cover such a wide range of material, and in view of the explosion of new knowledge in neuroscience this is an impressive feat. I find it satisfying to listen to only one voice, just as it is usually preferable to have one teacher in a course, especially if, as in the book, one can sense competence and sound judgement in the selection and interpretation of the material on which the book is based.

As a student I treasured a good textbook - which I defined as a book from which one could get, in a reasonable amount of time, some understanding of, and feeling for, a whole new area of knowledge. Later in life I returned to textbooks for teaching purposes, and also because old textbooks often give one insight into the knowledge and thoughts of an earlier time. Recently I looked at the central nervous system sections of Carpenter's Elements of Physiology, published in 1851. The chapters on the cerebellum and cerebrum were thoughtful and carefully reasoned on the basis of the facts available at the time. For example, it was known that the cerebellum was involved with complex movement, but Gall had proposed that it also had to do with sexual sensation. Carpenter did not think there was any evidence for Gall's notion, but gave it serious consideration. To compare this with misconceptions in our own time we need only recall the extensive discussion just a few years ago in regard to the claim that memory could be transferred by intraperitoneal injection of DNA.

Even if our understanding of the cerebral cortex has today reached a more advanced state, it is instructive to read Carpenter's discussion of the cortex, or, as he called it, the 'cerebrum'. At that time the 'sensorium' (the machinery of sensory processing) was thought to be located in subcortical structures, and 'the cerebrum is the instrument of all psychical operations', to 'Ideas', ranked as 'Emotional' and the 'Intelligential ... ', in other words, not too different from the present-day concept about the role of frontal lobes.

I make these comments because it seems appropriate to remind students that 'facts' stated in textbooks may be utterly wrong or may not necessarily give the whole story. At the same time it is true that from the student's point of view 'facts' are facts, particularly for the purpose of taking examinations, and the important thing is that they be stated correctly. It also helps if, as in the present case, the text reads easily and has numerous illustrations. 
The decision to update this book and to make an English translation is most welcome, since there is also a real need at colleges and medical schools outside of Scandinavia for this kind of book about the nervous system. As with Carpenter's book, perhaps in 100 years or so someone will pick up Ottoson's text and muse over our misconceptions, but also be impressed by the balance and soundness of the treatise. My prediction is that over many years, students, teachers and historians will find much in this book to learn and enjoy.

Harvard Medical School

Torsten Wiesel

Boston, MA

Professor and Chairman

May 1982 


\section{Preface}

'It is in the brain that the sensations arise, like seeing, hearing and smelling and out of these sensory perceptions memory and concept evolve; when memory and concepts have become consolidated there is knowledge.' (Plato in the dialogue Phaidon)

The cover of this book is from the work of the famous Spanish histologist and Nobel Laureate, Ramón $y$ Cajal. What it shows is a section of the visual cortex with its neurons and intricate network of neuronal connections. When studying such a preparation under the microscope, one looks into a world full of beauty and marvels. It is also a world of secrets and mysteries. When looking at the maze of dendrites and nerve fibres, it is tempting in the fantasy to try to follow the pathways of the signals from one neuron to another. In doing so, in the back of one's thinking the question often arises as to whether neuroscience will ever be able to explain the mind. In the last few decades, a number of new technologies have developed that have provided fascinating possibilities for exploring the functions of the brain, and we are at present beginning to understand some of the basic principles of its machinery.

The present book is an extended version of a textbook in Swedish that was developed from lectures presented to the medical students in their course of physiology. Ever since the first edition of the book appeared, I have also been repeatedly asked to make it available for English-speaking readers. For a long time, I have been reluctant to do this. The main reason for this is that I was deeply aware of the fact that the content of the book reflected my own interests in neuroscience too much. Furthermore, the book in its Swedish version is written in a personal narrative style that might be difficult to maintain in the process of transmutation into a foreign language. When finally I gave way after much persuasion, I tried to eliminate some of the most obvious shortcomings of the Swedish edition. However, when the book is now presented in English, I find that I have only been partly successful in this respect. As in the Swedish version, I have endeavoured to give a 'three-dimensional' account of the present state of our understanding of various aspects of nervous functions, instead of attempting to present a concise summary of available data. My aim has been to tell the story of how various problems in neuroscience have been attacked and solved in the past and how these advances form the basis of today's attempts to unravel the secrets of the nervous system.

It is inevitable that a book like this will reveal the interest of its author. As the reader may soon discover, I have a keen interest in the history of neuroscience; almost every chapter begins with a short historical note. The great emphasis that has been placed on sensory functions reflects a field of even more profound interest to me. However, I have strived not to let these interests encroach upon my aim of presenting an integrated picture of the manifold and marvellous functions of the sensory system.

This book was originally written for medical students. However, it might also be of value to students in psychology and biology as well as to students who, regardless of their scientific background, want to familiarise themselves with specific topics in neuroscience. The neuroanatomy required to understand various 
functions is presented when relevant in order to make the book suitable for those who are not familiar with these aspects of the nervous system.

As mentioned above, the rapid development of neuroscience in the last few decades has contributed greatly to our understanding of many aspects of nervous functions. However, the day is still certainly remote in the future when we shall be able to explain in physical and chemical terms the higher functions of the brain, such as learning and memory or emotions like love and hate, happiness and sorrow, hope and despair. The inner secrets of the brain will most likely remain hidden from us for an indefinite time in the future. To have the privilege as a neurophysiologist of being able to glance into this world of marvels is a fascinating experience, and I hope that I have been able in this book to convey a little of my own feelings and enthusiasm in this respect. 


\section{Acknowledgments}

The fact that there is only one author of the present book should by no means be understood that this is one man's work. I owe a great debt of gratitude to a number of colleagues who have contributed in one way or another to the completion of the book. First, I should like to acknowledge my deep obligation to Drs Charles Edwards, David Potter and Gordon Shepherd, who read the whole book, and to Drs Åke Flock, Jan Lännergren and Gerald Westheimer and Professor Torsten Wiesel, who read portions of it. Their comments and suggestions have added considerably to the clarity and organisation of presentation. I should like, too, to thank Professor Wiesel for contributing the Foreword. I also have the pleasure of acknowledging the competent editorial work carried out by Mrs Joan Dallos and Mrs Ellen Curtin. Most of the illustrations were drawn by Mrs Sandra Almenberg and Mrs Bibbi Mayrhofer, whose excellent work has added a great deal to the quality of the book.

I should like to extend my thanks to Mrs Grethe Shepherd, who prepared the English translation of the original Swedish edition of the book; her considerable work has formed the basis for this new edition.

Miss Olga Popoff has spent endless hours not only in typing and retyping the manuscript over and over again but also in bringing together all the material involved in the presentation. It is thanks to her unfailing help that it has been possible to complete this book. I would also like to thank Miss Gabrielle Ottoson, who gave me assistance in the final, most difficult, period of the work on the illustrations. Lastly, I wish to give special thanks to Miss Elizabeth Horne, Senior Editor of the Medical Division of Macmillan Press Ltd, for her endless patience and whole-hearted support, and to Mr R. M. Powell, who handled the production matters in a most efficient way. 